\title{
ANALISIS FAKTOR YANG MEMPENGARUHI HASIL BELAJAR IPA DAN LITERASI SAINS DI SMP NEGERI 1 MUARO JAMBI
}

Jufrida $^{1}$, Fibrika Rahmat Basuki ${ }^{2}$, Miko Danu Pangestu ${ }^{3}$, Nugroho Asmara Djati Prasetya ${ }^{4}$

${ }^{1,2,3}$ Prodi Pendidikan Fisika Universitas Jambi, Jambi, Indonesia

Email: alfattahmiko@gmail.com

\section{Info Artikel}

Diterima:

20 Januari 2019

Disetujui:

6 Agustus 2019

Dipublikasikan:

15 Desember 2019

\begin{abstract}
Abstrak :
Tujuan penelitian untuk menganalisis faktor yang mempengaruhi hasil belajar IPA dan literasi sains. Penelitian ini menggunakan pendekatan deskriptif kualitatif dengan jenis studi kasus. Subjek penelitian ini 1 guru dan siswa kelas IX SMPN 1 Muaro Jambi sebanyak 37. Instrumen penelitian menggunakan angket dan dokumentasi. Data dianalisis secara deskriptif kualitatif. Faktor yang mempengaruhi hasil belajar IPA dan literasi sains yaitu faktor psikologis (minat dan motivasi belajar), faktor keluarga (latar belakang pendidikan dan bimbingan orang tua), faktor sekolah (metode mengajar guru, sarana dan prasananan, dan bahan ajar/media pembelajaran IPA), dan kegiatan belajar diluar sekolah.
\end{abstract}

Kata kunci: Pembelajaran IPA, hasil belajar, literasi sains

\begin{abstract}
:
The research aims to analyze the factors that affect science learning outcomes and scientific literacy. This study used a qualitative descriptive approach with the case study type. The subject of this research was 1 teacher and grade IX students SMPN 1 Muaro Jambi as much as 37. The research instruments use questioner and documentation. Data were analyzed in a qualitative descriptive. The factors that affect the learning outcome and scientific literacy were psychological factors (interest and learning motivation), family factors (background of education and guidance of parents), school factors (teaching methods, teachers, facilities and institutions, and teaching materials/media), and learning activities outside school.
\end{abstract}

Keywords: Science learning, learning outcomes, science literacy

Copyright ( 92019 Edufisika: Jurnal Pendidikan Fisika

\section{Pendahuluan}

Literasi sains merupakan kemampuan seseorang dalam menggunakan pengetahuan sains. Literasi sains menurut OECD (2003) diartikan sebagai kemampuan menggunakan pengetahuan sains, mengidentifikasi pertanyaan, dan menarik kesimpulan berdasarkan buktibukti, dalam rangka memahami serta membuat keputusan berkenaan dengan alam dan perubahan yang dilakukan terhadap alam melalui aktivitas manusia. Pisa merupakan Programme Internationale for Student Assessment (PISA) yang merupakan suatu bentuk evaluasi kemampuan dan pengetahuan yang dirancang untuk peserta didik usia 15 tahun. Studi PISA dilakukan di beberapa negara 
maju dan berkembang mulai tahun 2000 dengan interval tiga tahun sekali. Bidang kajian yang diteliti dan dinilai meliputi literasi membaca (reading literacy), literasi matematika (mathematical literacy), dan literasis sains (scientific literacy). Hasil studi PISA sejak tahun 2000 hingga tahun 2015 menunjukkan peringkat indonesia terus meningkat. Tahun 2015 literasi sains peserta didik indonesia berada pada tingkat 69 dari 76 negara dengan skor 403. Skor ini mesih jauh dibawah skor rata-rata Internasional yang ditetapkan PISA yaitu (PISA,2015). Skor rata-rata indonesia yang masih tergolong rendah ini mencerminkan bahwa peserta didik di indonesia sebagaian besar belum mampu menganalisis dan mengaplikasikan konsep untuk menyelesaikan suatu masalah. Para peserta didik sangat pandai menghafal, namun masih kurang terampil dalam menggunakan pengetahuan yang dimiliknya.

Banyak faktor yang dapat menyebabkan rendahnya literasi sains di indonesia yaitu gender, ekonomi dan sosial, serta imigrasi (OECD, 2007). Rendah literasi sains menurut Fathurohman, dkk (2014) mengungkapkan rendahnya kemampuan literasi sains peserta didik di indonesia ini dipengaruhi oleh banyak hal, antara lain kurikulum dan sistem pendidikan, pemilihan metode dan model pengajaran oleh guru, sarana dan fasilitas belajar, sumber belajar, bahan ajar, dan lainnya. Literasi sains ada hubungan dengan hasil belajar IPA peserta didik disekolah. Di dalam penelitian Desi Nugrahei (2017) telah meneliti tentang pengaruh siklus belajar 5E terhadap kemampuan literasi sains pada materi sistem saraf manusia dengan tujuan penelitian salah satunya mengetahui hubungan antara kemampuan literasi sains dan hasil belajar kognitif peserta didik kelas XI SMA pada materi sistem saraf manusia. Didapat hasil penelitian menunjukkan bahwa hubungan kemampuan literasi sains dan hasil belajar diketahui melalui pengujian statistika korelasi pearson $(\mathrm{r}=.032)$ rmenunjukkan bahwa ada hubungan positif antara kemampuan literasi sains dan hasil belajar, artinya semakin tinggi kemampuan literasi sains, maka semakin tinggi hasil belajar peserta didik meskipun nilai korelasi antara keduanya dalam kategori rendah disebabkan oleh perbedaan pemahaman peserta didik terhadap suatu konsep sains, dalam hal ini sistem saraf manusia.

Menurut Rusman (2013) hasil belajar adalah sejumlah pengalaman yang diperoleh peserta didik yang mencangkup ranah kognitif, afektif, dan psikomotorik. Belajar tidak hanya penguasaan konsep teori mata pelajar saja, tapi juga penugasaan kebiasaan, persepsi, kesenangan, minat-bakat, penyesuaian sosial, macam-macam keterampilan, cita-cita, keinginan dan harapan. Sedangkan menurut Aminah (2018), hasil belajar merupakan kemampuan oleh peserta didik yang telah dicapai setelah mengikuti proses pembelajaran yang mencakup aspek kognitif, afektif dan psikomotorik. Capaian literasi sains peserta didik merupakan hasil dari berbagai faktor yang terkait antara yang dipelajarai di satuan pendidikan dengan pengelamannya dalam kehidupan sehari-hari. Baharudin dan wahyuni (2010) menyatakan faktor-faktor yang meengarahui hasil belajar dibagai dalam faktor internal dan faktor eksternal. Faktor internal merupakan faktor pendorong yang bersumber dari dalam diri peserta didik seperti Faktor fisiologis yang meliputi faktor jasmani, faktor kesehatan, faktor cacat tubuh dan faktor Psikologis meliputi motivasi, minat, bakat, kebiaasan belajar dan konsentrasi. Sedangkan faktor eksternal merupakan aspek yang berasal dari luar diri individu yang mempengaruhi hasil belajar peserta didik seperti faktor keluarga yang meliputi faktor dari latar belakang tingkat pendidikan orang tua, cara orang tua mendidik, relasi antar anggota keluarga, dan suansan rumah dan faktor sekolah yang mempengaruhi belajar ini mencakup yakni metode mengajar, metode belajar dan sarana dan prasarana. yang terakhir faktor masyarakat.

Faktor internal merupakan faktor-faktor yang berasal dari diri peserta didik yang mempengaruhi hasil belajar. salah satu faktor fisiologis yang meliputi motivasi belajar, minat belajar, dan kebiasaan belajar. seorang peserta didik yang memiliki motivasi dan minat yang tinggi akan melaksanakan tugas dari guru walaupun seberat apapun tugas tersebut. Sedangkan kebiasaan belajar merupakan salah satu faktor yang menpengaruhi hasil belajar atau prestasi belajar. kebiasaan belajar yang bagus juga dapat meningkatkan hasil belajar peserta didik.

Faktor eksternal merupakan faktorfaktor yang berasal dari luar diri peserta didik yang mempengaruhi hasil belajar. Faktor keluarga yang meliputi latar belakang pendidikan orang tua dan bimbingan orang tua. Menurut Tety,dkk (2016) Latar belakang pendidikan orang tua merupakan sesuatu yang 
besar pengaruh terhadap perkembangan anak. Latar belakang pendidikan orang tua juga dapat mempengaruhi cara orang tua membimbing anak-anak belajar dirumah. Menurut Mawarsih (2013) oerhatianorang tua terhadap aktivitas belajar anak dirumah mempunyai artipenting untuk meningkatkan semangat anak dalam meraih prestasi belajar yang optimal. Keberhasilan anak di sekolah didukung perhatian orang tua. Faktor sekolah yang mempengaruhi hasil belajar peserta didik yaitu metode mengajar dan saranan dan prasarana belajar. menurut Syaiful bahri (di dalam Fitriyani, 2013) metode belajar salah satu usaha yang tidak pernah guru tinggalkan adalah bagaimana memahami kedudukan metode sebagai salah satu komponen yang ikut ambil bagian keberhasilan kegiatan belajar mengajar.

Selain metode mengajar yang mempengaruhi hasil belajar peserta didik adalah saranan dan prasarana belajar. Menurut Syaiful Bahri (di dalam Fitriyani, 2013) fasilitas adalah kelengkapan yang menunjang belajar anak didik disekolah. Baik itu kelengkapan yang ada didalam kelas ataupun yang ada diluar kelas. Penelitian lebih khusus mengkaji faktor-faktor yang mempengerahui hasil belajar dan literasi sains yaitu a). Faktor psikologis yang meliputi motivasi belajar peserta didik,minat belajar, dan kebiaasan belajar peserta didik dalam belajar IPA; b) Faktor keluarga yang meliputi latar belakang pendidikan orang tua dan bimbingan orang tua peserta didik dalam pembelajaran; c). Faktor sekolah yang meliputi metode mengajar, metode belajar dan sarana dan prasaranan belajar di sekolah yang mempengaruhi faktorfaktor penyebab rendahnya hasil belajar IPA dan literasi sains peserta didik. Berdasarkan uraian di atas penulis melakukan tujuan untuk menganalasis faktor-faktor penyebab rendahnya hasil belajar IPA dan literasi sains peserta didik kelas XI di SMP Negeri 1 Muaro Jambi.

\section{Metodologi Penelitian}

Jenis Penelitian

Penelitian ini merupakan penelitian deskriptif kualitatif dengan metode studi kasus untuk mengetahui gambaran mengenai faktorfaktor penyebab rendahnya hasil belajar pembelajaran IPA dan Literasi sains peserta didik kelas IX SMP Negeri 1 Muaro Jambi.
Waktu dan Tempat Penelitian

Waktu penelitian dilaksanakan pada bulan Agustus s.d Oktober 2018. Tempat penelitian yaitu di SMP Negeri 1 Muaro Jambi.

Target/Subjek Penelitian

Populasi dalam penelitian ini adalah peserta didik kelas IX di SMP Negeri 1 Muaro Jambi tahun ajaran 2018/2019. Sampel penelitian ini adalah peserta didik kelas IX di SMP Negeri 1 Muaro Jambi. Teknik pengambilan sampel dilakukan dengan purposive sampling untuk mendapatkan sampel sekolah. Uji coba kepada 37 peserta didik kelas IX .

Prosedur

Prosedur penelitian yang dilakukan sebagai berikut:

1. Mengurus surat izin penelitian kepada pihak yang bersangkutan.

2. Menentukan subjek penelitian di SMP Negeri 1 Muaro Jambi

3. Melakukan pengambilan data penelitian menggunakan lembar angket peserta didik dan angket guru di SMP Negeri 1 Muaro Jambi.

4. Melakukan proses analisis terhdapat hasil data penelitian yang telah diambil

Instrumen Pengumpulan Data

Data yang diperoleh yang diambil dalam penelitian adalah data kualitatif. Instrumen yang digunakan dalam penelitian ini menggunakan lembar angket guru dan peserta didik dan dokumentasi. Pengambilan data kualitatif dilakukan dengan memberikan lembar angket peserta didik dan lembar angket guru digunakan dalam menentukan faktor-faktor penyebab rendahnya hasil belajar IPA dan literasi sains peserta didik..

Teknik analisis data

Pada penelitian ini menggunakan teknik model analisis interaktif (model Huberman dan Miles). Terdapat tiga langkah, yaitu:

1. Reduksi data (data reduction)

Reduksi data adalah proses pemilihan, pemusatan perhatian pada penyederhanaan, pengabstrakan, transformasik data kasar muncul dari catatan lapangan. Tahap reduksi data yang dilakukan dalam penelitian ini adalah

a. Mengumpulkan semua angket faktor psikologis, faktor sekolah, dan faktor keluarga.yang sudah disebarkan ke peserta didik 
b. Kemudian menghitung skor pada angket yang telah diisi oleh peserta didik kemudian menghiung presentase faktor psikologis, faktor sekolah, dan faktor keluarga kemudian menghitug presentase faktor penyebab rendahnya hasil belajar.

2. Penyajian data (data display)

Penyajian data adalah sekumpulan infromasi tersusun yang memberikan kemungkinan adanya penarika kesimpulan dan pemngambilan data. Adapun data yang disajikan adalah

a. Menyajikan hasil reduksi angket yang diisi peserta didik untuk menggambarkan presentase faktor psikologis, faktor sekolah, dan faktor keluarga.

b. Menyajikan dokumentasi dari nilai hasil belajar IPA peserta didik

c. Dari hasil penyajian data dilakukan analisis. kemudian analisis berupa pola baku yag dudukung oleh data.

3. Penarikan kesimpulan

Penarikan kesimpulan adalah hasil penelitian yang menjawab fokus penelitian berdasarkan hasil data. Simpulan disajikan dalam bentuk deskriptif untuk menjelaskan data.

\section{Hasil Penelitian dan Pembahasan}

Berdasarkan data yang diperoleh dari angket yang telah diisi oleh guru SMP Negeri 1 Muaro Jambi didapatkan bahwa guru tersebut peserta didik masih ada kesulitan dalam belajar IPA misalnya dalam permasalahan soal hitungan-hitungan. Guru tidak tahu mengenai literasi sains, peserta didik tidak pernah dilatih dalam menyelesaian soal-soal literasi sains seperti soal-soal PISA itu yang membuat kemampuan literasi sains peserta didik tidak tahu mengenai tentang literasi sains, peserta didik di dalam penugasaan hasil belajar IPA dan literasi sains peserta didik masih kurang baik. Dapat disimpulkan peserta didik tidak pernah dilatih dalam menyelesaian soal-soal literasi sains.

Berdasarkan data yang diperoleh hasil belajar dari dokumentasi dilihat dari ulangan IPA dengan rata-rata nilai mendapatkan nila 65,5. Nilai tersebut masih dibawah kriteria ketuntasan minimal (KKM) dengan nilai 70 . Peserta didik mendapatkan nilai dibawah kriteria ketuntasan minimal (KKM) presentase diperoleh sebesar 95\% itu menunjukkan bahwa nilai hasil belajar peserta didik masih rendah.

Berdasarkan hasil dari angket dengan indikator-indikator dari faktor tersebut yaitu untuk Faktor Psikologis dengan indikator motivasi dan minat 12 item, faktor keluarga meliputi indikator latar belakang pendidikan orang tua dan bimbingan orang tua pada peserta didik dalam belajar 2 item, faktor sekolah meliputi indikator kebiasaan dalam pembelajaran IPA (metode belajar peserta didik), indikator sarana dan prasarana sekolah 5 item, dan indikator Proses pembelajaran IPA diluar sekolah 3 item.

1. Faktor psikologis

Faktor psikologis merupakan salah satu mempengaruhi hasil belajar dan literasi sains dengan meliputi motivasi belajar, minat belajar dan kebiasaan pembelajaran IPA.

Siswa dalam pembelajaran IPA yang diukur disini adalah bagaimana motivasi dan minat siswa dapat dilihat pada grafik dibawah ini.

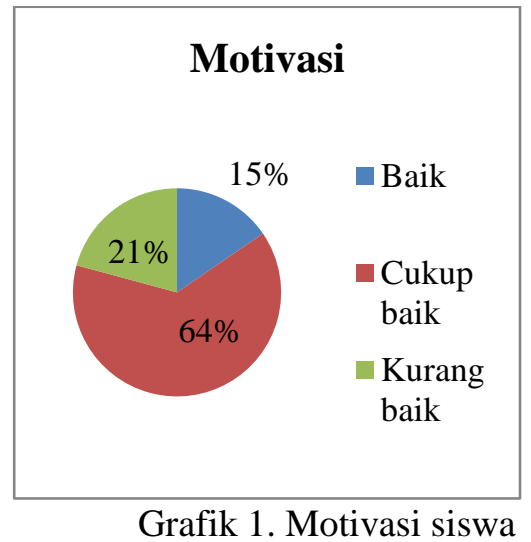

Dari grafik 1 dapat dilihat sebagian besar siswa memiliki motivasi siswa yang masih kategori cukup baik hal ini perlu ditingkat lagi dalam meningkatkan motivasi siswa dalam pembelajaran IPA.

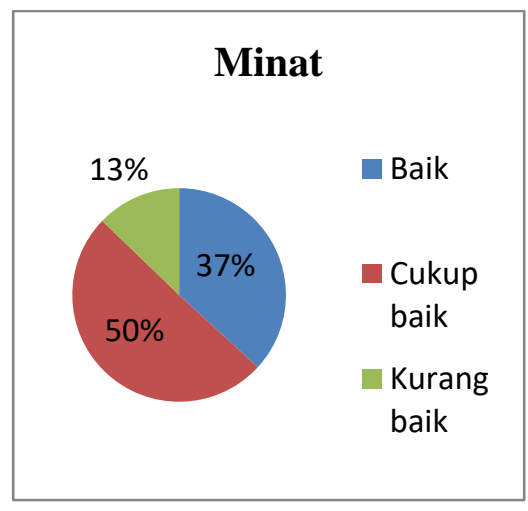

Grafik 2. Minat siswa

Dari grafik 1 dapat dilihat sebagian besar siswa memiliki minat siswa yang masih kategori cukup baik.Hal ini perlu ditingkat lagi dalam meningkatkan minat i siswa dalam 
pembelajaran IPA. Berdasarkan data dari angket faktor psikologis dengan indikator kebiasaan pembelajaran IPA peserta didik dapat dilihat pada grafik berikut ini.

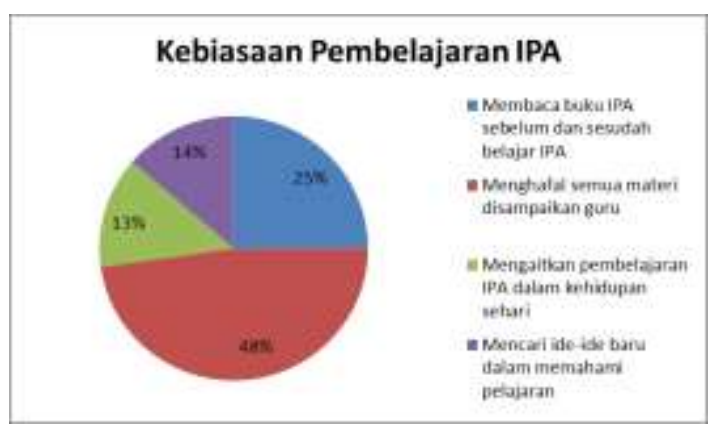

Grafik 3. Hasil kebiasaan belajar

Didapat dilihat dari grafik 3 diatas didapatkan hasil permasalahan dari indikator kebisaan belajar peserta didik yang didapatkan $48 \%$ peserta didik masih menghafal semua yang disampaikan guru tanpa menambah infromasi baru. Menurut Nur 1998 (di dalam wahyuni, 2015), memahami IPA tidak semata-mata menghafal fakta-fakta, tetapi juga belajar mengadaptasikan prinsip-prinsip dasar IPA ke dalam penerapan sehari-hari, hal ini tidak hanya membantu peserta didik menghubungkan IPA dengan dunia mereka sehari-hari, melainkan juga membantu peserta didik untuk membentuk keterampilan-keterampilan yang akan menjadikan mereka pengambil keputusan yang bertanggung jawab dan pemikir yang kritis.

\section{Faktor keluarga}

Faktor keluarga salah satu yang mempengaruhi hasil belajar dan literasi sains. Fakor keluarga yang meliputi yang mempengaruhi hasil belajar dan literasi sains yaitu latar pendidikan orang tua dan bimbingan orang tua belajar di rumah. Berdasarkan angket faktor keluarga dari indikator latar belakang pendidikan orang tua peserta didik. Dapat dilihat hasil penelitian yang diperoleh dari angket dengan indikator latar pendidikan orang tua peserta didik dapat dilihat pada grafik 3 dan grafik 4 berikut.

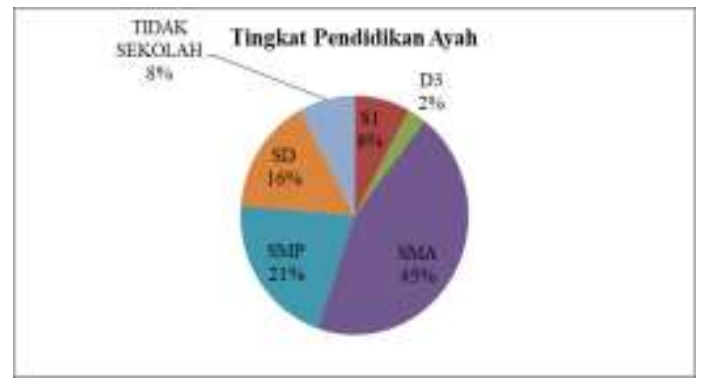

Grafik 4. Tingkat pendidikan Ayah

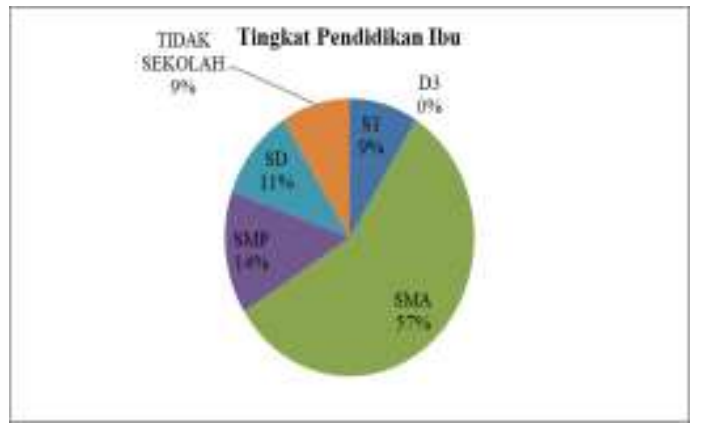

Grafik 5. Tingkat pendidikan Ibu

Terlihat dari grafik 4 dan grafik 5 latar belakang orang tua dimana tingkat pendidikan Ayah pada jenjang SI sebanyak 8\%, jenjang D3 $2 \%$, SMA sebanyak $45 \%$, jenjang SMP $21 \%$, jenjang SD $16 \%$ dan tidak sekolah sebesar $8 \%$. Sedangkan latar belakang orang tua dimana tingkat pendidikan Ibu pada jenjang SI sebanyak 9\% SMA sebanyak 57\%, jenjang SMP 14\%, jenjang SD $11 \%$ dan Tidak sekolah $9 \%$. Berdasarkan hasil data diatas dapat disimpulkan bahwa rata-rata latar pendidikan orang tua peserta didik masih berada di jenjang SMA.

Berdasarkan hasil dari Indoenesia National Assesment Programme (INAP) didapatkan hasil distribusi literasi sains berdasarkan pendidikan ayah di indonesia didapatkan hasil persentase tidak tamat/ tidak sekolah 31,9\%, tamat SD/MI 32,87\%, tamat SMP/MTS 33\%, tamat SMA 34\%, tamat D1/D2/D3/akdemik 35,6\% , tamat sarjana (S1) $35,73 \%$, tamat magister (S2/S3) 34,89\%, dan saya tidak tahu 33,93\%. Distribusi literasi sains berdasarkan pendidikan ibu di indonesia didapatkan hasil persentase tidak tamat/tidak sekolah 32,22\%, tamat SD/MI 32,6\%, tamat SMP/MTS 33,51\%, tamat SMA 34,68\%, tamat D1/D2/D3/akdemik 35,3\% , tamat sarjana (S1) 35,03 \%, tamat magister (S2/S3) $35,14 \%$, dan saya tidak tahu 34,02\%.

According to Dekar (2016) After the correlatoin between the parents'level of 
education and the academic achievement the student it can be concluede that, there is relationship betweenthese two variables. One can also conclude that the education level of parents does influence their children 'success in school. The result of the two variables which exa,ined the parents'edicational background and the effects on strudents'academic permofance indicated that there was signifiacant relationship. This finding complements the finding from other researchers that stated that status of parents does not only affect the academic perfomance of students but also maka it impossible for childer fro, low socio-ecomic background to compete well with their counterpart from high socio economic background under the same academuc environment. Menurut Dekar (2016) yang dilakukan setelah korelasi antara tingkat pendidikan orang tua dan presetasi akademik peserta didik dapat menyimpulkan bahwa ada hubungan antara dua variabel ini. Juga dapat menyimpulkan bahwa pendidikan orang tua mempengaruhi kesuksesan anak-anak mereka di sekolah. Hasil dua variabel yang memiliki latar belakang pendidikan orangtua dan mempengaruhi efek pada prestasi akademik peserta didik menunjukka bahwa ada hubungan yang signifikan. Penelitian lain menyatakan bahwa status orang tua tidak hanya mempengaruhi presetasi akademik peserta didik tetapi juga membuatnya tidak mungkin anakanak latar belakang sosial ekonomi rendah untuk bersaing dengan rekan mereka dari tempat latar belakang sosial ekonomi dibawah lingkungan akademik yang sama.

Berdasarkan Penelitian Tetty, et.al (2016) yang dilakukan menyatakan jika orang tua yang mempunyai latar belakang tingkat pendidikan tinggi maka semakin tinggi mengakibatkan hasil belajar meningkat. sedangkan menurut Dalyono (2012) menyatakan bahwa tinggi rendahnya pendidikan orang tua, besar kecilnya penghasilan, cukup kurang perhatian dan bimbingan orang tua, rukun atau tidaknya orang tua, akrab atau tidaknya hubungan orang tua dengan anak-anak, tenang atau tidaknya situasi dalam rumah, semua turut mempengaruhi hasil belajar peserta didik.

Berdasarkan angket faktor keluarga dari indikator bimbingan orang tua saat belajar IPA dirumah. Hasil penelitian didapatkan dari indikator bimbingan orang tua dapat dilihat datanya pada grafik 6 berikut ini .

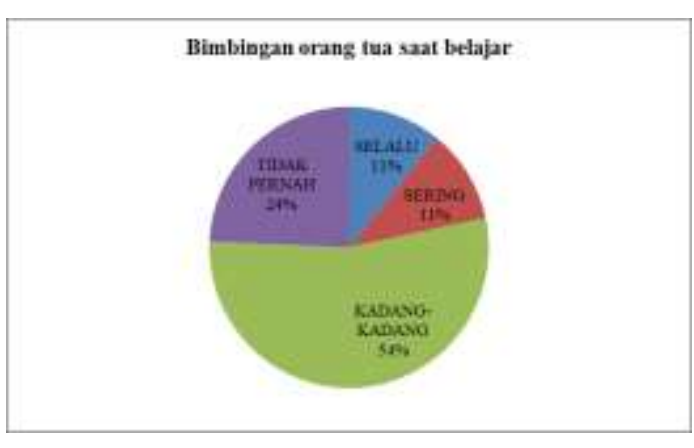

Grafik 6. Persentase bimbingan orang tua

Lihat dari grafik 6 angket peserta didik mengenai bimbingan orang tua peserta didik saat belajar persentase orang tua yang selalu mendampingi peserta didik belajar dirumah sebanyak $11 \%$, orang tua yang sering mendampingi peserta didik belajar dirumah sebesar $11 \%$, orang tua yang kadang-kadang mendampingi peserta didik belajar dirumah sebesar $54 \%$, dan orang tua yang tidak pernah mendampingi peserta didik belajar dirumah sebesar $24 \%$. Berdasarkan dari hasil diatas dapat simpulkan bahwa terdapat masalah mengenai bagaimana bimbingan orang tua peserta didik sangat jarang membimbing atau mendampingi peserta didik belajar dirumah. Hal ini sangat berdampak bagi dari hasil belajar IPA dan literasi sains peserta didik.

Berdasarkan penelitian Firda (2016) yang menyatakan dengan bimbingan orang tua dalam belajar akan mendapatkan hasil belajar peserta didik. bimbingan belajar merupakan bimbingan dalam menemulan cara belajar yang tepat, dalam memilih program studi yang sesuai, dan dalam mengatasi kesukaran-kesukaran yang timbul berkaitan dengan tuntutan-tuntan belajar disuatu instisusi pendidikan.

\section{Faktor sekolah}

Berdasarkan pemberian angket guru didapatkan metode yang digunakan dalam pembelajaran IPA yaitu metode eksperimen dan metode diskusi. Model pembelajaran yang sering digunakan model pembelajaran inquiry, dan pendekatan yang sering digunakan yaitu pendekatan kontektual dan pendekatan SETS.

Berdasarkan angket studi pendahuluan sarana dan prasarana sekolah SMP Negeri 1 Muaro Jambi didapatkan mendukungnya peralatan laboratorium IPA dalam pembelajaran IPA disekolah, mendukungnya ketersedian buku IPA diperpusatakan mendukung semua peserta didik yang ada disekolah, cukup mendukungnya 
dan ketersdiaan media pembelajaran IPA di sekolah dalam pembelajaran IPA.

Berdasarkan penelitian Murniarti, dkk (2016) menyatakan bahwa ada pengaruh signifikan saran dan prasaran dengan hasil belajar peserta didik. hal ini dibuktikan dengan karena nilai $\mathrm{t}$ hitung $>\mathrm{t}$ tabel $(8,889>1.9850)$ dengan taraf signifikan 5\% sehingga Ha diterima Ho ditolak. Sedangkan pendapat Baharudin dan wahyuni (2010) salah satu saran meningkatkat hasil belajar adalah perlu sarana dan prasaranan yang mendukung di sekolah. Berdasarkan dari angket lama peserta didik belajar IPA di luar sekolah dilihat pada grafik 7 berikut ini.

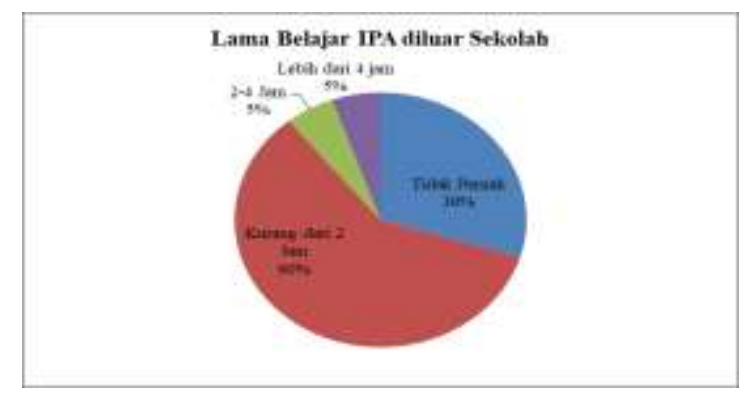

Grafik 7. Lama belajar IPA diluar sekolah

Terlihat dari grafik tentang proses belajar IPA di luar sekolah bahwa mendapatkan hasil bahwa peserta didik mendapatkan sebesar $30 \%$ tidak pernah belajar IPA di luar sekolah, kurang dari 2 jam belajar IPA diluar sekolah $60 \%, 2-4$ jam belajar IPA diluar sekolah 5\% dan lebih dari 4 jam belajar IPA diluar sekolah sebesar $5 \%$. Berdasarkan grafik diatas rata-rata peserta didik lama belajar IPA diluar sekolah kurang dari 2 jam setiap minggunya. Selanjutnya rata-rata peserta didik tidak pernah ikut pelajaran tambahan (les) di luar sekolah. Dapat simpulkan bahwa rata-rata $60 \%$ peserta didik kurang dari 2 jam lama belajar di luar sekolah.

Berdasarkan hasil dari data Indoenesia National Assesment Programme (INAP) didapatkan hasil distribusi literasi sains berdasarkan sehari di indonesia peserta didik belajar diluar sekolah didapatkan hasil bahwa 01 jam belajar IPA diluar sekolah 35,78 \%, 2-3 jam belajar IPA diluar sekolah 37,89\%, >3 jam belajar IPA diluar sekolah 19,05 dan tidak mengisi 7,29. Berdasarkan hasil data dapat disimpulan rata-rata peserta didik di indonesia belajar IPA diuar sekolah 2-3 jam setiap minggunya.

\section{Simpulan dan Saran \\ Simpulan}

Berdasarkan deksripsi, analisis data di pembahasan disimpulkan bahwa faktor menyebabkan rendahnya hasil belajar IPA dan literasi sains peserta didik di SMP Negeri 1 Muaro Jambi mendapatkan hasil yaitu :

1. Faktor Psikologis dengan minat belajar minat belajar dan motivasi belajar cukup bagus dan dari indikator kebiasaan belajar IPA didapatkan rata-rata kebiasaan peserta didik atau metode belajar masih sering menghafal semua materi yang disampaikan guru dan tidak menambah infromasi dari yang lain.

2. Faktor keluarga dengan indikator latar belakang orang tua didapatkan hasil rata-rata jenjang SMA dan indikator bimbingan orang tua didapatkan hasil rata-rata orang tua kurang membimbing anaknya dalam belajar dirumah.

3. Faktor sekolah, indikator metode mengajar guru sudah bagus, guru memiliki metode, model dan pendekatan pembelajaran bervariasi dalam mengajar dikelas, indikator pembelajaran diluar sekolah rata-rata peserta didik belajar diluar sekolah kurang dari 2 jam, peserta didik sama sekali tidak mengikuti jam tambahan diluar atau les dan indikator saran dan prasaranan sudah mendukung dalam pembelajaran.

Saran

Berdasarkan simpulan, disarankan untuk peserta didik hendaknya dapat mengubah kebiasaan belajar mereka yang cuma menghafal semua materi yang disampaikan guru dan tidak menambah infromasi dari yang lain. Peserta didik harus dibiasakan tidak menghafal materi dan harus mencari infromasi baru. Orang tua harus membimbing dan membantu anak dalam belajar dirumah.

Perlu dilakukan lebih lanjutnya mengenai solusi dari permasalahan pembelajaran IPA. Faktor-faktor lain dalam penyebab pembelajaran IPA dan solusi dari penyebab hasil belajar IPA dan literasi sains, seperti lingkungan sekolah dan tempat bermain peserta didi.

\section{Daftar Pustaka}

Aminah, Siti. 2018. Efektivitas Metode Eksperimen Dalam Meningkatkan Hasil Belajar Pada Pembelajaran Ilmu Pengetahuan Alam di Sekolah Dasar. Jurnal Indragiri, Vol.1, No. 04. 
Baharuddin \& Esa Nur Wahyuni. (2015). Teori Belajar \& Pembelajaran Yogyakarta : Ar-Ru11 Media.

Dalyono. M. (2012) . Psikologis Pendidikan. Jakarta: Rineka Cipta.

Dekar,Y (2016). The Influence of Parents Educational Background on the Academic Achievemenat of the Government High School Students in Thimphu. DOI: 22.144.157.211.

Falela, F. Pengaruh Bimbingan Belajar Terhadap Peningkatan Hasil Belajar IPA peserta didik kelas IV SDN 1 Midang tahun pelajaran 2015/2016. Nusa Tenggaran Barat: Universitas Mataram.

Fitriyani. (2013). Pengaruh Penggunaan Metode Pembelajaran dan Fasilitas Belajar terhadap Prestasi Belajar Mata Pelajaran Ekonomi. Oikonomia,2(4):309-314.

Mawarsih, E.S,. Susilaningsih, Hamidi. (2013). Pengaruh perhatian orang tua dan motivasi belajar terhadap prestasi belajar peserta didik SMA Negeri Jumapolo. JUPE UNS, 1(3),1-13.

Miles, M. B., Huberman, A.M. (1984). Qualitative Data Analysis: A Sourcebook of New Methods. California: SAGE publications Inc.

Murniarti. D, dkk. (2016). Pengaruh sarana dan prasaranan terhadap hasil belajar peserta didik pelajaran ekonomi SMA Negeri 1 Sungai Ambawang. Jurnal Pendidikan dan Pembelajaran 5(11).
Nassaji, Hossein. (2015). Qualitative and Descriptive Research: Data TypeVersus Data Anlysis. Languange Teaching Research, 19(3), 129-132.

Nugraheni, Desi. (2017). Pengaruh siklus belajar 5E terhadap kemampuan literasi sains pada materi sistem saraf manusia. Jurnal Prodi Pendidikan Biologi 2(4), 178-188.

Organilation For Economic Cooperation and Development. (2003). The PISA 2003. Assessment Framework. Paris.OECD.

Rusman. (2017). Belajar dan Pembelajaran Berorientasi Standar Proses Pendidikan. Jakarta : Kecana.

Sugiyono. (2013) Metode Penelitian Kuantitatif Kualitatif dan $R \& D$. Bandung: Alfabeta.

Tety, N. C, Nyoman, S \& Sugen, U. (2016). Pengerahu Latar belakang tingkat pendidikan Orang tua dan gaya belajar terhadap hasil belajar peserta didik pada kelas IV SDN Kecamatan Sananwetan Kota Blitar. Jurnal Pendidikan: Teori, Penelitian, dan Pengembangan, 3(2),486491.

Wahyuni, Retno Dwi (2015). Peningkatan Prestasi Belajar Peserta didik Dalam Pembelajaran IPA Materi Bunyi dengan Menerapkan Metode Kooperatif Model Jigsaw di Kelas VIII A SMP Negeri 2 Kwadungan Tahun Pelajaran 2013/2014.Jurnal Florea, 2(1),13-17. 